\title{
ANALISIS KOMPARASI PENGHASILAN DRIVER GO-JEK DAN GRAB TERHADAP STANDAR UPAH MINIMUM REGIONAL KOTA BEKASI PADA SAAT PANDEMI COVID-19
}

\author{
Aditya Ramadhan ${ }^{1}$, Eri Bukhari ${ }^{2}$ \\ Program Studi Manajemen, Fakultas Ekonomi dan Bisnis, Universitas Bhayangkara Jakarta Raya, Bekasi ${ }^{1,2}$ \\ satriapiningits03@gmail.com ${ }^{1}$, eri_bukhari@yahoo.com ${ }^{2}$ \\ Penulis untuk Korespondensi/E-mail: eri_bukhari@yahoo.com
}

\begin{abstract}
Abstrak
Tujuan penelitian ini adakah untuk mengetahui perbandingan pendapatan driver Go-jek dan Grab yang bekerja secara full time apakah berada di atas atau di bawah besarnya Upah Minimum Regional yang berlaku di Kota Bekasi pada saat konsisi normal dan pada saat pandemi covid - 19. Jenis penelitian ini merupakan adalah studi kasus.dan metode yang dipergunakan dalam penelitian ini adalah deskriptif kuantitatif dengan teknik pengumpulan data berupa penyebaran kuesioner pada sejumlah responden yang merupakan driver Gojek dan Grab yang bekerja penuh waktu sebanyak 70 orang driver, dengan tenggang waktu selama 30 hari. Hasilnya menunjukkan bahwa pendapatan bersih yang diterima driver Go-jek dan Grab yang bekerja penuh waktu, mayoritas berada di atas besarnya UMR yang berlaku di Kota Bekasi, dan menurun drastis sampai mencapai dibawah Upah Minimum Regional selama masa pandemi Covid-19.
\end{abstract}

Kata Kunci : Pendapatan, Go-Jek, Grab, Upah Mimimum Regional, dan Covid-19.

\begin{abstract}
The purpose of this study is to determine the income ratio of Go-jek and Grab drivers who work full time whether they are above or below the Regional Minimum Wage in Bekasi during normal conditions and during the Covid-19 pandemic. is a case study. and the method used in this research is quantitative descriptive with data collection techniques in the form of distributing questionnaires to a number of respondents who are Gojek and Grab drivers who work full time as many as 70 drivers, with a grace period of 30 days. The results show that the net income received by Go-jek and Grab drivers who work full time, the majority are above the UMR size prevailing in Bekasi City, and decreased dramatically until they reached below the Regional Minimum Wage during the Covid -19 pandemic.
\end{abstract}

Keywords : Income, Go-Jek, Grab, Regional Minimum Wage, and Covid-19

\section{PENDAHULUAN}

Sebagai bagian dari masyarakat modern dengan mobilitas yang tinggi, kebutuhan transportasi merupakan hal yang sangat penting dalam kehidupan sehari- hari, terutama di era digitalisasi saat ini, dimana kebutuhan tersebut diikuti dengan perkembangan teknologi yang pesat. Saat ini teknologi sudah menjadi hal yang tidak dapat di pisahkan dengan segala kegiatan manusia di dunia, sehingga kondisi ini dimanfaatkan menjadi peluang bagi pelaku bisnis untuk terjun ke bisnis transportasi. Seiring dengan berjalannya waktu, kebutuhan terhadap transportasi semakin meningkat di karenakan bertambahnya jumlah penduduk di suatu wilayah, namun pertambahan penduduk tersebut umumnya lebih cepat dari pertambahan produksi sehingga menimbulkan bertambahnya jumlah angkatan kerja. Fenomena di daerah perkotaan adalah meningkatnya jumlah penduduk yang tinggi yang disebabkan karena tingkat kelahiran yang tinggi maupun urbanisasi. Hal ini berimbas juga dengan fenomena pertumbuhan penduduk yang semakin meningkat 
tidak sebanding dengan jumlah lapangan pekerjaan yang ada saat ini. dan tentunya mengakibatkan timbulnya potensi pengangguran terbuka.

Kota Bekasi merupakan salah satu kota yang mengalami permasalahan tersebut. Sebagai kota penyangga ibukota Jakarta, banyak para pendatang mencari lapangan pekerjaan di daerah Bekasi, ini disebabkan Bekasi merupakan daerah berkembang terutama dibidang industri yang memiki lapangan pekerjaan khususnya industri manufaktur. Tidak hanya di sektor industri, kepadatan penduduk di Kota Bekasi memiliki dampak yang besar terhadap moda transportasi yang dibutuhkan.

Pada tahun 2014, merupakan awal yang sangat fenomenal bagi perkembangan layanan transportasi yang seiring dengan globalisasi, dimana financial teknologi memunculkan jasa transportasi online, yaitu Grab dan Go-Jek. Keberadaan Grab dan Go-JEK tidak dapat dipungkiri dapat membantu dan mensejahterakan perekonomian masyarakat dengan membuka lapangan kerja baru, sedangkan bagi mereka yang sudah bekerja dengan menjadi pengemudi ojek online dapat memiliki penghasilan tambahan dengan hanya memanfaatkan kendaraan roda dua dan HP android yang mereka miliki, dapat lebih produktif dalam berpenghasilan. Berkahnya lainnya adalah dengan adanya jasa transportasi online seperti Grab dan GO-JEK dapat menjadi alternatif pekerjaan kepada mereka yang belum memiliki pekerjaan tetap. Menjadi driver/pengemudi maupun mitra ojek online tidak terikat oleh jam kerja dan jumlah pendapatan yang bergantung pada jumlah pesanan yang di selesaikan.

Pada akhir tahun 2019 dunia diguncang dengan muncul wabah penyakit yang mematikan yaitu wabah virus Corona Virus Corona atau severe acute respiratory syndrome coronavirus adalah virus yang menyerang sistem pernafasan. Virus Corona dapat menyebabkan gangguan ringan pada sistem pernafasan, infeksi paru- paru yang berat, hingga kematian. Khusus di Indonesia kasus ini pertama kali ditemukan pada 2 warga Depok, Jawa Barat awal Maret tahun 2020, kemudian penyebaran virus tersebut berkembang dengan pesat ke seluruh Indonesia tidak terkecuali di Bekasi. Hal ini dikarenakan banyak warga yang tidak mengikuti himbauan dari pemerintah yaitu untuk tetap dirumah dan melakukan social distancing atau menjaga jarak.

Penyebaran virus corona (Covid - 19) terdampat terhadap kondisi perekonomian masayarakat, termasuk perusahaan transportasi online yang terkena imbas karena pemerintah menerapkan kebijakan kerja dari rumah (Work From Home/ WFH), sehingga terjadi penurunan dratis terhadap orderan yang mereka terima. Berdasarkan fenomena tersebut penulis bermasud melakukan penelitian yang bertujuan:

1. Untuk mengetahui apakah pendapatan Driver Grab full time berada di atas atau di bawah besarnya UMR (Upah Minimum Regional) Pemkab/kota Bekasi pada kondisi normal dan pada pandemi Covid - 19 .

2. Untuk mengetahui apakah pendapatan Driver GO-JEK full time berada di atas atau di bawah besarnya UMR (Upah Minimum Regional) Pemkab/kota Bekasi pada kondisi normal dan pada pandemi Covid - 19 .

\section{TINJAUAN PUSTAKA}

\section{Pendapatan}

Salah satu indikator utama ekonomi untuk mengukur kemampuan ekonomi masyarakat adalah tingkat pendapatan masyarakat. Indikator yang dimaksud hanya bersangkutan dengan pendapatan dan pengeluaran, akan tetapi yang lebih penting adalah mengetahui besarnya perbandingan antara penerimaan dengan pengeluaran. Pendapatan dapat digunakan sebagai ukuran dalam menilai keberhasilan suatu usaha dan juga faktor yang menentukan dalam kelangsungan suatu usaha. Pendapatan dapat diartikan sebagai jumlah uang yang diterima oleh seseorang atau badan usaha selama jangka waktu tertentu, (Phahlevi, 2013). Dalam Teori Ekonomi Mikro. menurut Sadono Sukirno (2009 : 85) dpendapatan adalah perolehan yang berasal dari biaya - biaya faktor produksi atau jasa - jasa produktif. Sedangkan Rahardja dan Manurung (2001) mengemukakan pendapatan adalah total penerimaan (uang dan bukan uang) seseorang atau rumah tangga dalam periode tertentu.

Pengertian tersebut menunjukkan bahwa pendapatan adalah seluruh perolehan baik yang berasal dari biaya faktor produksi maupun total output yang dihasilkan untuk seluruh produksi dalam suatu perekonomian dalam jangka waktu tertentu. Berdasarkan beberapa definisi diatas, dapat disimpulkan bahwa pendapatan merupakan penghasilan yang diterima oleh masyarakat berdasarkan kinerjanya, baik pendapatan uang maupun bukan uang selama periode tertentu, baik harian, mingguan, bulanan maupun tahunan. 
Upah

Upah adalah hak pekerja/buruh yang diterima dan dinyatakan dalam bentuk uang sebagai imbalan dari pengusaha atau pemberi kerja kepada pekerja/buruh yang ditetapkan dan dibayarkan menurut suatu perjanjian kerja, kesepakatan, atau peraturan perundang undangan, termasuk tunjangan bagi pekerja/buruh dan keluarganya atas suatu pekerjaan dan/atau jasa yang telah atau akan dilakukan (Pasal 1 angka 30 Undang - Undang Nomor 13 Tahun 2013 tentang Ketenagakerjaan).

Menurut Rivai (2005), upah diberikan sebagai bentuk balas jasa yang adil dan layak diberikan kepada para pekerja atas jasa - jasanya dalam mencapai tujuan organisasi. Upah dibayarkan kepada pekerja berdasarkan jam kerja, jumlah barang yang dihasilkan atau banyaknya pelayanan yang diberikan..

\section{Jenis-jenis Upah}

Upah dalam berbagai sumber kepustakaan Hukum Ketenagakerjaan Bidang Hubungan Kerja menurut Asyhadie (2007, h. 70) dapat dikemukakan sebagai berikut:

1. Upah Nominal; yaitu sejumlah uang yang dibayarkan secara tunai kepada pekerja/buruh yang berhak sebagai imbalan atas pengerahan jasa - jasa atau pelayanannya sesuai dengan ketentuan - ketentuan yang terdapat dalam perjanjian kerja.

2. Upah Riil ; yaitu adalah uang nyata, yang benar - benar harus diterima seorang pekerja/buruh yang berhak. Upah riil ini ditentukan oleh daya beli upah tersebut yang akan tergantung dari : 1) besar atau kecilnya jumlah uang yang diterima; 2) besar atau kecilnya biaya hidup yang diperlukan

3. Upah Hidup; yaitu upah yang diterima pekerja/buruh relatif cukup untuk membiayai keperluan hidupnya secara luas, yang bukan hanya kebutuhan pokoknya, melainkan juga kebutuhan sosial keluarganya, seperti pendidikan, asuransi, rekreasi, dan lain - lain.

4. Upah Minimum; yaitu upah terendah yang akan dijadikan standar oleh pengusaha untuk menentukan upah yang sebenarnya dari pekerja/buruh yang bekerja di perusahaannya. Upah minimum ini umumnya ditentukan oleh pemerintah dan setiap tahun kadangkala berubah sesuai dengan tujuan ditetapkannya upah minimum yaitu: 1.) Untuk menonjolkan arti dan peranan pekerja/buruh sebagai subsistem dalam suatu hubungan kerja; 2.) Untuk melindungi kelompok kerja dari adanya sistem pengupahan yang sangat rendah dan yang secara materiil kurang memuaskan; 3.) Untuk mendorong kemungkinan diberikannya upah yang sesuai dengan nilai pekerjaan yang dilakukan; 4.) Untuk mengusahakan terjaminnya ketenangan dan kedamaian kerja dalam perusahaan; 5)Mengusahakan adanya dorongan peningkatan dalam standar hidup secara normal.

\section{Upah Minimum Regional}

Adalah upah minimum yang berlaku untuk satu daerah, yaitu satu provinsi atau satu Kabupaten/Kota. Perusahaan yang beroperasi di suatu daerah wajib menyesuaikan upah terendahnya dengan UMR di daerah tersebut. Ketentuan mengenai UMR terdapat dalam Peraturan Menteri Tenaga Kerja no. 1 tahun 1999 tentang Upah Minimum.

Tabel 1. Upah Minimum Regional di Kawasan Jabodetabek Tahun 2020

\begin{tabular}{|c|r|}
\hline Kabupaten/Kota & Upah Minimum Kab/Kota \\
\hline DKI Jakarta & Rp $4.276 .349,00$ \\
\hline Kota Bekasi & Rp $4.589 .708,00$ \\
\hline Karawang & Rp $4.594 .324,00$ \\
\hline Tangerang & Rp 4.199.030,00 \\
\hline
\end{tabular}

Sumber: https://www.gajiumr.com/gaji-umr-jawabarat/, 2020

\section{METODOLOGI PENELITIAN}

Desain penelitian yang digunakan pada penelitian ini menggunakan data primer dengan pendekatan kuantitatif. Metode Statistik yang digunakan adalah Independent Sample T Test. Uji ini digunakan untuk mengetahui ada atau tidaknya perbedaan rata - rata antara dua kelompok sampel yang tidak berhubungan, dan jika ada perbedaan, rata - rata manakah yang lebih tinggi.. Metode ini dilakukan dengan membandingkan pendapatan driver Go-Jek dan Grab full time dengan UMR yang sudah ditentukan oleh Pemkab/Kota Bekasi untuk tahun 2020 pada kondisi normal dan pandemi Covid - 19 dengan menggunakan aplikasi SPSS.

Untuk penentuan jumlah sampel pada driver Go-jek dan Grab, peneliti menggunakan Sample Linear Time Function, hal ini dikarenakan jumlah driver ojek online di Kota Bekasi pada setiap tahunnya tidak tetap. Sample Linear Time Function adalah penentuan jumlah sampel 
berdasarkan estimasi kendala waktu (Endang S. Sari 2012:58) Besarnya jumlah sampel (n) yang diambil menggunakan rumus perhitungan sebagai berikut:

$$
\mathrm{n}=\frac{\mathrm{T}-\mathrm{t0}}{\mathrm{t} 1}
$$

Keterangan:

$\mathrm{n}$ = Banyaknya sample yang terpilih

$\mathrm{T}=$ Waktu yang tersedia untuk penelitian (30 hari $\times 24 \mathrm{jam}=720 \mathrm{jam} / \mathrm{bulan}$ )

t0 = Waktu tetap pengambilan sample (10 $\mathrm{jam} / \mathrm{hari} \times 30$ hari $=300 \mathrm{jam} / \mathrm{bulan}$ )

$\mathrm{t} 1$ = Waktu yang digunakan untuk sampling unit/ mengisi kuesioner $(1 / 5 \mathrm{jam} / \mathrm{hari} \times \mathrm{x} 30$ hari $=$ $6 \mathrm{jam} / \mathrm{bulan}$ ).

Sehingga sample yang didapat adalah:

$$
\begin{aligned}
& \mathrm{n}=\frac{720-300}{6} \\
& \mathrm{n}=70 \text { responden }
\end{aligned}
$$

\section{ANALISA DAN PEMBAHASAN}

Uji Independent Sample $\mathrm{T}$ Test ini digunakan untuk mengetahui ada atau tidaknya perbedaan rata - rata antara dua kelompok sampel yang tidak berhubungan. Metode ini dilakukan dengan membandingkan pendapatan driver Go-Jek dan Grab full time dengan UMR yang sudah ditentukan oleh Pemkot/ Kota Bekasi untuk tahun 2020 pada kondisi normal dan pandemi Covid - 19 dengan menggunakan aplikasi SPSS versi 25. UMR yang berlaku di Kota Bekasi sebesar Rp. 4.589.708,00.

Hasilnya dapat dilihat sebagai berikut:

1. Uji Independent Sample T Test pada Go-Jek

Hasil dari Uji Independent Sample T Test Pada Pendapatan Go-Jek Dalam Kondisi Normal dan Pandemi Covid-19 dapat dilihat dalam table

\begin{tabular}{|c|c|c|c|c|c|}
\hline \multicolumn{6}{|c|}{ Group Statistics } \\
\hline & Kondisi & $\mathrm{N}$ & Mean & $\begin{array}{c}\text { Std. } \\
\text { Deviati } \\
\text { on }\end{array}$ & $\begin{array}{l}\text { Std. } \\
\text { Error } \\
\text { Mean }\end{array}$ \\
\hline \multirow{2}{*}{$\begin{array}{l}\text { Hasil } \\
\text { Pendapat } \\
\text { an }\end{array}$} & Normal & 35 & 18,0571 & 2,88956 & ,48843 \\
\hline & Covid-19 & 35 & 11,5429 & 1,85255 & ,31314 \\
\hline
\end{tabular}
berikut:

Tabel 2. Hasil Uji Independent Sample T Test Pada Go-Jek

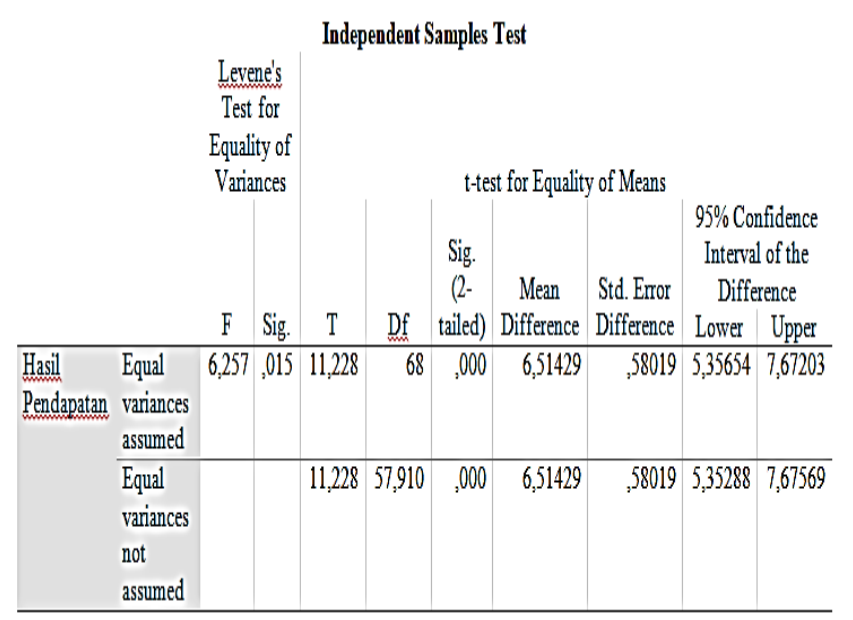

Sumber : data primer yang diolah 2020.

Dasar pengambilan keputusan dalam Uji t tersebut adalah:

1. Jika nilai sig $<0,05$ atau $t$ hitung $>\mathrm{t}$ tabel maka terdapat perbedaan antara variabel $X$ dan variable.

2. Jika nilai sig. $>0,05$ atau $\mathrm{t}$ hitung $<\mathrm{t}$ tabel maka tidak terdapat perbedaan pengaruh variabel $\mathrm{X}$ dan variabel $\mathrm{Y}$.

$\mathrm{T}$ tabel $=\mathrm{t}(\alpha / 2 ; \mathrm{n}-\mathrm{k}-1)=\mathrm{t}(0,025 ; 32)=2,037$

Berdasarkan tabel 2. dapat disimpulkan bahwa t hitung diperoleh sebesar 11,228 > t tabel 2,037 atau $\mathrm{H}_{0}$ ditolak dan $\mathrm{H}_{\mathrm{a}}$ diterima, yang berarti terdapat perbedaan antara pendapatan Go-Jek pada kondisi normal dan pada saat pandemi Covid - 19 . Hal ini terjadi karena pengaruh dari jumlah orderan, jam kerja, waktu dan tempat mencari orderan, jumlah pendapatan perhari, bonus yang didapat, jumlah deposit saldo, dan ratarata pengeluaran perhari seperti biaya bensin, $\mathrm{T}$ tabel $=$ $\mathrm{t}(\alpha / 2 ; \mathrm{n}-\mathrm{k}-1)=\mathrm{t}(0,025 ; 32)=2,037$ biaya makan, dan biaya pulsa. Pada waktu pandemi orderan semakin sedikit dan ada pembatasan sosial berskala besar / PSBB sehingga driver tidak diizinkan untuk mengangkut penumpang di sebagian daerah alasan inilah yang membuat perbedaan pendapatan pada saat normal dan pada masa pandemi.

2. Uji Independent Sample T Test pada Grab

Hasil dari Uji Independent Sample T Test Pada Pendapatan Grab dalam Kondisi Normal dan Pandemi Covid-19 dapat dilihat dalam table berikut; 
Tabel 3. Hasil Uji Independent Sample T Test Pada Grab

\begin{tabular}{|l|l|c|c|c|c|}
\multicolumn{7}{c|}{ Group Statistics } \\
\hline \multirow{2}{*}{} & Kondisi & $\mathrm{N}$ & \multicolumn{1}{|c|}{ Mean } & $\begin{array}{c}\text { Std. } \\
\text { Deviation }\end{array}$ & $\begin{array}{c}\text { Std. } \\
\text { Error } \\
\text { Mean }\end{array}$ \\
\hline $\begin{array}{l}\text { Hasil } \\
\text { Pendapat } \\
\text { an Grab }\end{array}$ & Normal & 35 & 17,7429 & 2,33065 &, 39395 \\
\cline { 2 - 6 } & $\begin{array}{l}\text { Covid- } \\
19\end{array}$ & 35 & 12,6000 & 2,53447 &, 42840 \\
\hline
\end{tabular}

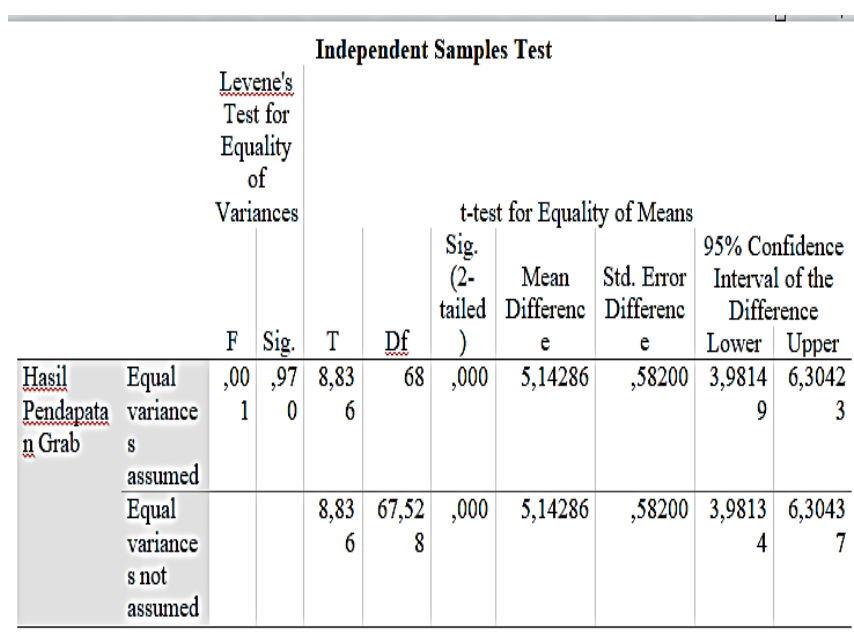

Sumber : data primer yang diolah 2020.

Berdasarkan tabel 3. dapat disimpulkan bahwa t hitung diperoleh sebesar 8,836 > t tabel 2,037 atau $\mathrm{H}_{0}$ ditolak dan $\mathrm{H}_{\mathrm{a}}$ diterima, yang berarti terdapat perbedaan antara pendapatan Grab pada kondisi normal dan saat pandemi Covid - 19. Hal ini terjadi karena pengaruh dari jumlah orderan, jam kerja, waktu dan tempat mencari orderan, jumlah pendapatan perhari, bonus yang didapat, jumlah deposit saldo, dan rata-rata pengeluaran perhari seperti biaya bensin, biaya makan, dan biaya pulsa. Pada waktu pandemi orderan semakin sedikit dan ada pembatasan sosial berskala besar/ PSBB sehingga driver tidak diizinkan untuk mengangkut penumpang di sebagian daerah alasan inilah yang membuat perbedaan pendapatan pada saat normal dan pada masa pandemi.

3. Uji Independent Sample T Test Pada

Pendapatan Go-Jek dan Grab

Hasil uji apakah ada perbedaan pendapatan driver G-Jek dan Grab bisa dilihat pada table dibawah ini:
Tabel 4. Hasil Uji Independent Sample T Test Pada Go-Jek dan Grab

\begin{tabular}{|l|l|l|l|l|l|}
\multicolumn{7}{c|}{ Group Statistics } \\
\hline & & & & \begin{tabular}{c} 
Std. \\
Std. \\
\cline { 2 - 6 }
\end{tabular} & $\begin{array}{c}\text { Std. } \\
\text { Error } \\
\text { Deviation }\end{array}$ \\
\hline $\begin{array}{l}\text { Hasil } \\
\text { Pendapatan } \\
\text { Driver }\end{array}$ & $\begin{array}{l}\text { Go- } \\
\text { jek }\end{array}$ & 35 & 18,0571 & 2,88956 &, 48843 \\
\cline { 2 - 6 } & Grab & 35 & 17,7429 & 2,33065 &, 39395 \\
\hline
\end{tabular}

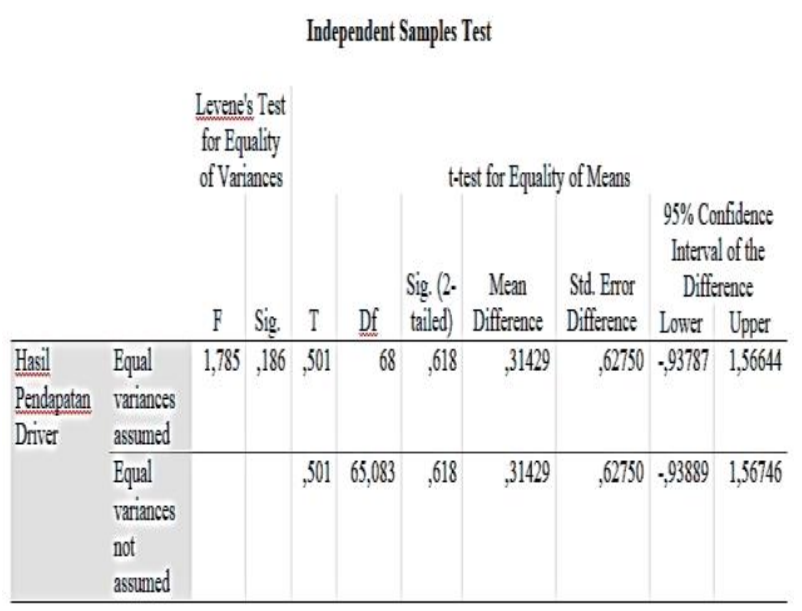

Sumber : Output SPSS 25.05 data diolah, 2020

Berdasarkan tabel 4. dapat disimpulkan bahwa $\mathrm{t}$ hitung diperoleh sebesar $0,501<\mathrm{t}$ tabel sebesar 2,037 atau H0 diterima dan Ha ditolak, yang berarti tidak terdapat perbedaan antara pendapatan Go-Jek dan Grab.

\section{KESIMPULAN}

\section{Kesimpulan}

Berdasarkan hasil analisis pada bab sebelumnya, maka kesimpulan yang dapat diambil dari penelitian ini yaitu sebagai berikut :

1. Pendapatan sebulan yang diterima driver Gojek pada kondisi normal mayoritas berada diatas besarnya UMR (Upah Minimum Regional) Pemkab/kota Bekasi. Pendapatan sebulan yang diterima driver pada saat pandemi Covid-19 mengalami penurunan yaitu berada dibawah besarnya UMR (Upah Minimum Regional) dan dibawah besarnya pendapatan pada saat normal.

2. Pendapatan sebulan yang diterima driver Grab pada kondisi normal mayoritas berada diatas besarnya UMR (Upah Minimum Regional) Pemkab/kota Bekasi. Pendapatan sebulan yang diterima driver pada saat pandemi Covid-19 mengalami penurunan yaitu berada dibawah besarnya UMR (Upah Minimum 
Regional) dan dibawah besarnya pendapatan pada saat normal.

Implikasi Manajerial Berdasarkan kesimpulan penelitian yang sudah dijelaskan diatas, terdapat saran yang bermanfaat bagi perusahaan maupun bagi para driver ojek online. Adapun saran yang dapat peneliti berikan yaitu sebagai berikut :

1. Bagi Manajemen Perusahaan agar dapat mempertimbangkan dan masukan tentang peraturan, syarat, dan kebijakan yang saling menguntungkan antara perusahaan dan driver ojek online dalam beroperasi pada saat kondisi normal maupun dalam kondisi pandemi covid-19.

2. Bagi para driver agar lebih terpacu untuk bersaing dan berinovasi pada saat bekerja terutama bagi yang bekerja full time dan tetap menjaga kesehatan dalam kondisi pandemi covid-19.

Pada penelitian yang dilakukan oleh peneliti saat ini, objek yang digunakan yaitu perusahaan Go-Jek dan Grab yang melayani moda transportasi online saja. Untuk penelitian yang akan datang akan lebih baik untuk memperluas objek penelitian dengan menggunakan beberapa perusahaan di beberapa sektor dalam transportasi yang lain meliputi sektor darat, sektor laut, dan sektor udara lainnya.. Bagi peneliti lain yang ingin membahas kembali dengan objek yang sama dengan penelitian ini, disarankan untuk mengumpulkan jumlah sampel yang lebih banyak dan memperbanyak variabel lain agar mendapatkan hasil analisis yang lebih valid.

\section{DAFTAR PUSTAKA}

Wibowo, J. B. (2018). Analisis Perbandingan Antara Pendapatan Driver Go-Jek Full Time Dan Upah Minimum Regional (Studi Kasus di Kota Yogyakarta).

Cahyadi, D. (2017). Analisis Faktor-faktor yang Mempengaruhi Pendapatan Driver Ojek
Online (Studi Pada Go-Jek Malang). Jurnal Ilmiah Mahasiswa FEB, 5(2).

Giri, P. C., \& Dewi, M. H. U. (2017). Analisis Faktor-Faktor yang Mempengaruhi Pendapatan Driver GOJEK di Kota Denpasar, Bali. E-Jurnal Ekonomi Pembangunan Universitas Udayana, 6(6), 948-975.

Sugiyono. (2013). Metode Penelitian Kuantitatif Kualitatif dan R \& D. Bandung: Alfabeta.

Ningsih, T. M. W. (2019). Analisis Dampak Keberadaan Ojek Online Terhadap Pendapatan Ojek Konvensional di Kota Bojonegoro (Doctoral dissertation, Universitas Bojonegoro).

Pahlevi, Rico. (2013). Faktor - Faktor Yang Mempengaruhi Pendapatan Petani Padi Sawah Di Kota Padang Panjang.

Bagoes Mantra, Ida. (2003). Demografi Umum. Yogyakarta. Pustaka Pelajar.

Herdiansyah, Haris. (2009). Metodologi Penelitian Kualitatif. Jakarta. Salemba Humanika.

Lembaga Demografi Fakultas Ekonomi Universitas Indonesia. (2010). Dasar Dasar Demografi. Edisi - 2 . Jakarta. Salemba Empat.

Martono, Nanang. (2014). Metode Penelitian Kuantitatif : Analisis Isi dan Analisis Data Sekunder., Edisi Revisi 2.

Winarni, F dan Sugiyarso. (2006). Administrasi Gaji dan Upah. Cetakan Pertama. Yogyakarta. Pustaka Widyatama.

Untari, D. T. (2018). Penelitian Kontemporer Bidang Ekonomi dan Bisnis. Cetakan Pertama. Purwokerto. Pena Persada.

https://www.gojek.com/, diakses pada 4 April 2020.

https://www.grab.com/id/, diakses pada 5 April 2020.

https://onlinejek.com/berapa-penghasilandrivergojek-saat-ini/, diakses pada 23 Maret 2020.

https://www.infojek.com/perhitungangrabbike/, diakses pada 27 Maret 2020.

https://www.gajiumr.com/gaji-umr-jawa-barat/, 2020 